\title{
Penerapan Metode Pq4r Untuk Meningkatkan Keterampilan Membaca Pemahaman Siswa Sekolah Dasar Kelas Tinggi
}

\author{
Dede Risma Ginanjar ${ }^{1}$, Din Azwar Uswatun ${ }^{2}$, Arsyi Rizqia Amalia ${ }^{3}$ \\ Program Studi Pendidikan Guru Sekolah Dasar, Universitas Muhammadiyah Sukabumi \\ dederismaginanjar@gmail.com
}

\begin{abstract}
ABSTRAK
Penelitian ini bertujuan untuk mendeskripsikan peningkatan keterampilan membaca pemahaman melalui penerapan metode PQ4R. Metode penelitian yang digunakan adalah Penelitian Tindakan Kelas (PTK) dengan desain penelitian menggunakan model Kemmis dan Mc Taggart yang dilakukan sebanyak dua siklus. Setiap siklus terdiri dari perencanaan, pelaksanaan tindakan dan pengamatan serta refleksi. Partisipan dalam penelitian ini adalah siswa kelas V SD Negeri Cikole Kota Sukabumi sebanyak 23 siswa, terdiri dari 13 siswa laki-laki dan 10 orang perempuan. Teknik pengumpulan data pada penelitian ini menggunakan test dan observasi, dengan instrumen berupa soal keterampilan membaca pemahaman. Pengumpulan data non tes berupa lembar obervasi, catatan lapangan dan dokumentasi. Teknik analisis data yang digunakan adalah teknik kuantitatif deskriptif. Hasil penelitian pada prasiklus melalui tes indikator keterampilan membaca pemahaman, menunjukkan ketuntasan $30,43 \%$. Kemudian meningkat pada siklus I mencapai ketuntasan $43,47 \%$. Sedangkan pada siklus II hasil tes menunjukkan ketuntasan mencapai $82,60 \%$. Adapun peningkatan secara keseluruhan dengan perhitungan rumus N-Gain diperoleh skor 0,68 dengan kategori sedang. Kesimpulan dari penelitian ini bahwa keterampilan membaca pemahaman siswa di kelas tinggi meningkat melalui penerapan metode PQ4R pada tahun ajaran 2018/2019.
\end{abstract}

Kata Kunci : Metode PQ4R, Keterampilan Membaca Pemahaman, Siswa Kelas Tinggi.

Abstract: This research purpose is for describe the improvement of reading comprehension skills through the application of the PQ4R method. The research method used was Classroom Action Research (CAR) with a research design using the Kemmis and Mc Taggart models which were carried out in two cycles. Each cycle consists of planning, implementing actions and observing and reflecting. Participants in this study were 23 students of class V of Cikole Elementary School in Sukabumi City, consisting of 13 male students and 10 female students. Data collection techniques in this study used test and observation, with instruments in the form of reading comprehension skills. Collection of non-test data in the form of observation sheets, field notes and documentation. The data analysis technique used is descriptive quantitative techniques. The results of the study on the pre-cycle through an indicator of reading comprehension skills showed $30.43 \%$ completeness. Then increasing in the first cycle reached completeness $43.47 \%$. While in the second cycle the test results showed completeness reached $82.60 \%$. The overall increase with the calculation of the N-Gain formula obtained a score of 0.68 with the medium category. The conclusion of this study is that reading comprehension skills of high class students increase through the application of the PQ4R method in the 2018/2019 school year.

Keywords: PQ4R Method, Reading Comprehension Skill, High Class Students

Jurnal Perseda Vol 2, No.3 Tahun 2019 | 140 


\section{A. PENDAhuluan}

Bahasa merupakan salah satu alat yang digunakan dalam kehidupan seharihari untuk berkomunikasi, berinterkasi antara individu dengan individu, individu dengan kelompok. Bahasa memiliki peran yang utama di dalam kehidupan yaitu, sebagai alat untuk menyampaikan informasi seperti pikiran, perasaan atau gagasan dan untuk mengidentifikasi diri. Melalui bahasa, individu dapat mengembangkan kemampuan intelektual, sosial dan emosional (Depdiknas, 2006: 317). Selain itu, bahasa digunakan sebagai sarana untuk memperoleh pengetahuan dan informasi. Mengingat pentingnya peranan bahasa dalam kehidupan manusia, maka sudah seharusnya bahasa dimasukkan kedalam dunia pendidikan.

Pembelajaran Bahasa Indonesia diarahkan untuk meningkatkan kemampuan siswa dalam berkomunikasi secara lisan maupun tulisan dengan baik dan benar serta menumbuhkan apresiasi terhadap hasil karya sastra (Depdiknas, 2006: 317). Oleh sebab itu, pembelajaran bahasa Indonesia tidak difokuskan pada penguasaan komponen kebahasaan, akan tetapi harus menguasi komponen keterampilan bahasa.

Menurut Suhendar \& Supinah (2010: 1) ada empat Keterampilan bahasa diantaranya: (1) Keterampilan menyimak (2) Keterampilan berbicara

Keterampilan membaca, dan (4) Keterampilan menulis. Setiap keterampilan memiliki keterkaitan satu sama lain dengan proses yang mendasari bahasa Indonesia. Keterampilan membaca merupakan salah satu keterampilan yang harus dikuasi oleh siswa sekolah dasar dalam pembelajaran bahasa Indonesia, keterampilan membaca sangat menunjang keberhasilan siswa dalam belajar, bukan hanya dalam pembelajaran bahasa Indonesia saja, akan tetapi keterampilan membaca sangat menunjang keberhasilan semua bidang studi.

Pentingnya membaca, khusunya membaca pemahaman patut ditingkatkan karena membaca pemahaman merupakan salah satu proses mendapatkan informasi yang terkandung dalam teks bacaan (Abidin, 2012: 147). Hal yang harus diperhatikan dalam membaca adalah kemampuan seseorang dalam memahami teks bacaan secara menyeluruh, dengan demikian disebut dengan membaca pemahaman. Menurut Nutall (dalam Somadayo, 2011: 10) Tujuan membaca pemahaman adalah pembaca dapat memahami atau menemukan makna dalam teks bacaan, berupa informasi, pengetahuan dan bahkan ungkapan senang atau sedih.

Berdasarkan hasil wawancara yang telah dilakukan pada tanggal 14 November 2018 di SDN Cikole kelas V A, kesulitan siswa dalam membaca pemahaman pembelajaran bahasa Indonesia antara lain: 1) siswa belum mampu memahami isi teks bacaan; 2) siswa belum mampu menemukan kalimat utama dalam teks bacaan; 3) siswa belum mampu menjawab pertanyaan sesuai 
dengan teks bacaan; 4) siswa belum mampu menyimpulkan isi teks bacaan.

Selain melakukan wawancara peneliti melakukan observasi pada tanggal 15 November 2018, berdasarkan hasil observasi masih banyak siswa yang kesulitan ketika dihadapkan dengan teks bacaan. Kerapkali siswa menanyakan isi teks yang telah dibacanya kepada guru. Dimulai dari apa yang diceritakan dalam teks, hingga menanayakan jawaban dari pertanyaan yang berkaitan dengan isi teks tersebut. Siswa memiliki konsentrasi yang rendah ketika melakukan kegiatan membaca sehingga kesulitan dalam mengingat informasi yang terdapat dalam teks termasuk menjawab pertanyaan yang jawabanya terdapat dalam teks bacaan.

Pada pembelajaran tematik, pembelajaran seringkali dikaitkan dan bermula dari teks bacaan yang didalamnya terdapat materi yang akan dipelajari siswa sementara kemampuan untuk memahami teks bacaan masih kurang. Sehingga menyebabkan nilai rata-rata bahasa Indonesia dari hasil UAS semester ganjil tahun ajaran 2018/2019 nilai siswa yang mencapai KKM dari seluruh siswa kelas V A yang berjumlah 23 siswa diantaranya 8 (36\%) orang siswa yang berhasil mencapai KKM, sedangkan 14 (64\%) orang siswa tidak mencapai KKM.

Pemaparan permasalahan di atas menunjukkan bahwa keterampilan membaca siswa masih rendah. Pembelajaran membaca belum sepenuhnya menggunakan pembelajaran inovatif dan metode yang diterapkan tidak bervariasi. Kegagalan proses pembelajaran Bahasa Indonesia dapat pula disebabkan oleh siswa.
Siswa masih pasif dalam proses pembelajaran, siswa cenderung bosan ketika dihadapkan dengan kegiatan membaca, siswa beranggapan bahwa membaca yang terpenting adalah bahan bacaan dari guru selesai dibaca tanpa memahami isi dari bacaan tersebut dan rendahnya minat baca dalam diri siswa. Berdasarkan uraian permasalahan di atas, maka pembelajaran harus divariasi dengan beberapa metode, untuk meningkatkan keterampilan membaca pemahaman siswa.

Berdasarkan pemaparan di atas, maka penulis memilih menerapkan metode PQ4R dalam penelitian ini. Menurut Suprijono (2013: 122) Metode PQ4R ini diawali dengan (Preview) siswa membaca selintas, langkah berikutnya (Question) siswa membuat pertanyaan untuk dirinya sendiri, (Read) membaca secara saksama untuk menemukan jawaban dari pertanyaan yang telah dirumuskan, yang selanjutnya (Reflect) siswa tidak cukup mengingat atau menghafal, namun yang terpenting adalah mereka mencoba memahami apa yang telah dibacanya dan menghubungkan dengan pengetahuan yang telah diketahui sebelumnya, yang selanjutnya (Recite) siswa diminta untuk merenungkan kembali informasi yang telah dipelajari, yang terakhir adalah (Review) siswa diminta untuk membuat kesimpulan atau intisari dari teks bacaan.

Sejalan dengan penelitian terdahulu oleh Muhsin (2010: 126) yang menjelaskan hasil penelitiannya bahwa metode PQ4R dapat meningkatkan keaktifan belajar siswa dan meningkatnya kemampuan membaca pemahaman siswa, dan diikuti dengan penelitian Wungkana (2015: 7) yang 
menjelaskan bahwa metode PQ4R dapat meningkatkan pembelajaran keterampilan membaca pemahaman bahasa Indonesia, selain itu penggunaan metode PQ4R dapat memudahkan siswa dalam memahami teks bacaan.

Berdasarkan penjelasan di atas dengan menerapkan metode PQ4R, akan meningkatkan keterampilan membaca pemahaman siswa. Selain itu dengan menggunakan metode PQ4R akan menghasilkan efisiensi dan efektifitas membaca pemahaman yang lebih baik dan meningkatnya minat baca siswa. Maka dari itu penulis bermaksud menerapkan metode PQ4R untuk meningkatkan keterampilan membaca pemahaman.

\section{B. METODE PENELITIAN}

Penelitian ini merupakan Penelitian Tindakan Kelas (PTK). PTK adalah penelitian yang berbasis problem atau permasalahan proses pembelajaran di kelas. Penelitian ini bertujuan mengungkap penyebab masalah dan sekaligus memberikan sosuli, terhadap masalah tersebut. Penelitian ini bertujuan untuk menerapkan keterampilan membaca pemahaman siswa dengan menerapkan metode PQ4R. Secara kolaboratif penelitian ini melibatkan guru yang menjadi wali kelas dan siswa sebagai pelaku dalam proses pembelajaran. Model penelitian yang digunakan adalah dengan menggunakan model spiral yang dikembangkan oleh Kemmis dan Mc. Taggart (dalam Wiriaatmadja, 2012: 66) secara garis besar terdapat empat tahapan yang lazim digunakan, yaitu: perencanaan (planning), tindakan (acting), pengamatan (observing), serta refleksi (reflecting). Menurut
Wiriaatmadja (2012: 29) "Penelitian tindakan kelas adalah bagaimana sekelompok guru dapat mengorganisasikan kondisi praktek pembelajaran mereka, dan belajar dari pengalaman mereka sendiri." Siklus kegiatannya, tahap pelaksanaan dan pengamatan dilakukan dengan jangka waktu yang bersamaan.

Partisipan dalam penelitian ini adalah siswa kelas V A SD Negeri Cikole Kota Sukabumi sebanyak 23 siswa, peneliti 1 orang, dan guru kelas 1 orang. Sedangkan subjek dalam penelitian ini yaitu keterampilan membaca pemahaman siswa kelas V A, dalam penelitian digunakan nama inisial siswa untuk mempermudah penyajian dan penelitian. Peran peneliti dalam penelitian ini adalah memberikan tindakan, pengumpulan data, penganalisis data dan sekaligus pelapor hasil penelitian.

\section{Teknik Pengumpulan Data}

Teknik pengumpulan data pada penelitian ini menggunakan dua teknik yaitu Tes dan Non tes. Teknik tes berupa Pretest dan Postest sedangkan non test berupa wawancara, observasi dan catatan lapangan.

\section{Teknik Analisi Data}

Penelitian ini menggunakan analisis data kuantitaf deskriptif. Hasil tes dan non tes siswa dianalisis dengan mengacu tabel kriteria menurut Hamzah, (2014: 279) yang dapat dilihat pada Tabel 1 berikut.

\begin{tabular}{|c|c|}
\hline $\begin{array}{c}\text { Tingkat } \\
\text { Keberhasilan (\%) }\end{array}$ & Kategori \\
\hline $86-100 \%$ & Sangat Baik \\
\hline $71-85 \%$ & Baik \\
\hline $56-70 \%$ & Cukup \\
\hline $41-55 \%$ & Rendah \\
\hline $20-40 \%$ & Sangat Rendah \\
\hline
\end{tabular}


Tabel 3.7 Kriteria Presentase

Keberhasilan Belajar Siswa

(Sumber: Hamzah, 2014: 279)

Menghitung persentase ketuntasan belajar dengan menggunakan rumus:

$$
p=\frac{\text { Jumlah siswa yang tuntas belajar }}{\text { Jumlah Siswa }} \times 100 \%
$$

(Sumber: Hamzah, 2014: 279)

\section{HASIL PENELITIAN DAN PEMBAHASAN}

Pelaksaan tindakan siklus I selama 2 kali pertemuan yang dilaksanakan pada hari Sabtu 30 Maret dan Sabtu 06 April 2019. Pelaksanaan tindakan diamati oleh observer yang terdiri dari 4 orang teman sejawat mengamati aktivitas guru, aktivitas siswa, serta melakukan dokumentasi selama proses pembelajaran berlangsung. Pelaksanaan tindakan siklus I terdiri dari empat tahapan yaitu perencanaan, pelaksanaan, observasi, dan refleksi.

Pelaksanaan proses pembelajaran menggunakan model Metode $P Q 4 R$ dapat meningkatkan keterampilan membaca pemahaman siswa. Ketuntasan pada prasiklus dapat dilihat pada Tabel 4.1 sebagai berikut.

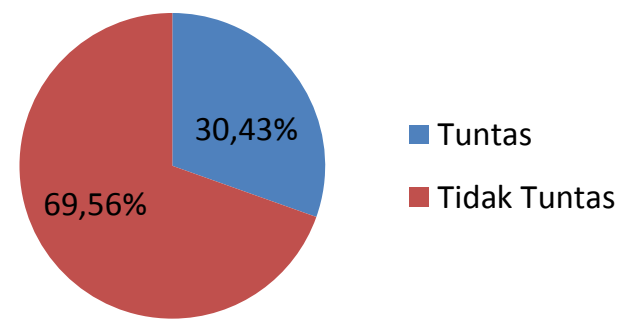

\section{Gambar 4.1 Diagram Ketuntasan Membaca Pemahaman Pra Siklus}

Berdasarkan gambar 4.1 hasil ketuntasan membaca pemahaman pada pra siklus bahwa hanya 7 orang $(30,43 \%)$ siswa yang tuntas, Hal ini dikarenakan permasalahan yang dialami adalah rendahnya proses keterampilan membaca pemahaman siswa kelas V SD Negeri Cikole Kota Sukabumi. Oleh karena itu, perlu diadakan tindakan untuk memperbaiki dan meningkatkan keterampilan membaca pemahaman siswa yang masih rendah dengan menggunakan metode PQ4R, dengan cara melakukan tindakan perbaikan pembelajaran menggunakan metode PQ4R diharapkan dapat membantu siswa dalam membaca pemahaman, siswa tidak lagi mengalami kesulitan dalam memahami bacaan, serta menjadikan siswa aktif dan antusias dalam mengikuti pembelajaran. Perbandingan setiap indikator pra siklus dan Siklus I disajikan sebagai berikut.

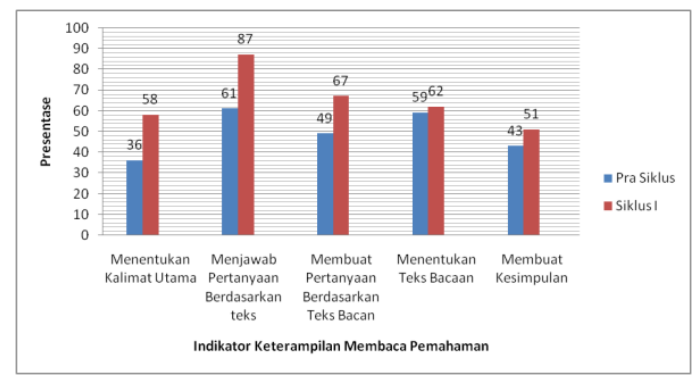

\section{Gambar 4.2 Diagram Perbandingan Pra Siklus dan Siklus I Keterampilan Membaca Pemahaman}

Berdasarkan data pada gambar 4.2 maka dapat dilihat ketercapaian dari setiap indikator keterampilan membaca pemahaman siswa pada siklus I sudah menunjukkan peningkatan dari hasil sebelumnya. Terlihat masih banyak siswa yang mengalami kesulitan disetiap indikator membaca pemahaman, sehingga nilai yang 
diperoleh belum maksimal. Adapun deskripsi dari setiap indikator adalah sebagai berikut.

Peningkatan keterampilan membaca pemahaman dengan menerapkan metode PQ4R pada pembelajaran Bahasa Indonesia di kelas VA telah disesuaikan indikator menurut Nutall (dalam Somadayo 2011: 11) adalah sebagai berikut:

1) Menentukan Kalimat Utama

Gagasan pokok/kalimat utama merupakan bagian yang penting dalam sebuah paragraf. Untuk menentukan gagasan pokok sebuah paragraf dalam cerita dapat ditempuh dengan cara sebagai berikut: a) memperhatikan paragraf sebagai suatu unit bacaan. b) membaca kalimat pertama dalam paragraf secara cermat. dan c) Jika kalimat pertama ternyata bukan kalimat topik, maka pembaca membaca kalimat terakhir dalam paragraf (Lestari, 2011: 28). Berdasarkan teori di atas sangat berbeda dengan fakta dilapangan dibuktikan dengan nilai rata-rata pada indikator ini mencapai 58 dengan kategori sedang. Siswa masih belum menuliskan kalimat utama secara lengkap, bahkan masih ada siswa yang sama sekali tidak menjawab. Hal tersebut karena siswa belum paham bagaiamana cara menentukan kalimat utama.

2) Menjawab pertanyaan berdasarkan teks

Siswa menjawab pertanyaan akan tetapi masih ada yang tidak sesuai dengan teks bacaan. Hal tersebut disebabkan karena siswa belum sepenuhnya memahami isi teks bacaan dengan baik dan siswa tidak sungguhsungguh ketika membaca. Sehingga pada indikator menjawab pertanyaan berdasarkan teks jumlah ketercapaian indikator mencapai rata-rata 87 dengan kategori Tinggi. Sebagaimana yang dikemukakan menurut Dalman (2014: 13) membaca adalah memahami secara detail dan menyeluruh isi bacaan dan mendapatkan informasi tentang sesuatu. Akan tetapi berdasarkan fakta dilapangan siswa belum sepenuhnya memahahi isi teks bacaan.

3) Membuat pertanyaan berdasarkan teks Siswa membuat pertanyaan berdasrkan teks bacaan akan tetapi masih ada beberapa siswa yang membuat pertanyaan akan tetapi tidak berkaitan dengan teks bacaan. Hal tersebut disebabkan karena siswa belum paham mengenai kalimat tanya, dan penggunaan tanda tanya diakhir kalimat. Sehingga pada indikator ini jumlah ketercapaian indikator mencapai rata-rata 67 dengan katogori sangat sangat tinggi.

4) Menentukan butir-butir bacaan

Masih banyak siswa yang belum mampu menemukan butir-butir bacaan dengan tepat. Hal ini disebabkan karena siswa belum sungguh-sungguh dalam membaca teks bacaan, terlihat dari masih ada siswa yang mengobrol ketika dimnta untuk membaca teks bacaan. Pada indikator masih belum maksimal, dilihat dari jumlah ketercapaian indikator mencapai 62 dengan kategori Tinggi.

5) Membuat kesimpulan

Menurut Lestari (2011: 28) kesimpulan bacaan selalu diartikan sebagai suatu ringkasan. Kesimpulan 
juga disamakan maknanya dengan ikhtisar. Tujuan kesiampulan dalam bacaan adalah untuk mengetahui gagasan pokok/pikiran utama, dan gagasan dalam sebuah cerita, dimana kesimpulan dapat memperjelas pemahaman terhadap wacana yang dibaca. Hal ini sangat berbeda dengan fakta dilapangan.

Berdasarkan temuan dilapangan siswa belum mampu menuliskan kesimpulan atau merangkum dari apa yang telah dibacanya, masih ada siswa yang menuliskan kembali seluruh teks bacaan, ada juga siswa yang menuliskan beberapa kalimat akan tetapi keluar dari teks bacaan. Hal ini karena siswa belum mampu memahami secara keseluruhan apa yang telah dibacanya dan siswa belum mampu menuangkan kembali menggunakan bahasa sendiri. Sehingga pada indikator ini mencapai nilai rata-rata 51 dengan kategori sedang.

Keterampilan membaca pemaham setiap indikator yang telah dijelaskan di siklus I memperoleh nilai peningkatan yang berbeda padahal perlakukan dan tindakan yang diberikan sama. Hal tersebut dikarenakan sebelumnya siswa kurang dibiasakan untuk membaca atau karena siswa tidak memiliki kegemaran dalam membaca. Sehingga hal tersebut terbawa saat pembelajaran. Syarbini (dalam Ihsani, Kurniah dan Suprapti, 2018: 50-51) pembiasaan yang dilakukan saat proses pembelajaran akan membawa kegemaran dan kebiasan tersebut menjadi semacam adat kebiasaan sehingga menjadi bagian tidak terpisahkan dari kepribadiannya, termasuk kebiasaan siswa dalam membaca. Adapun Ketuntasan hasil test Membaca Pemahaman tersaji pada tabel 4.3 sebagai berikut.

\section{Tabel 4.3 Ketuntasan Hasil Test Membaca Pemahaman Pada Siklus I}

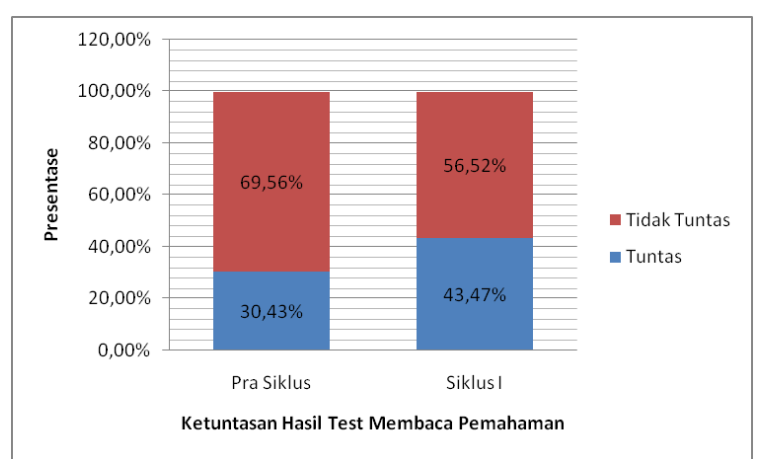

Sumber: Hasil Olah Data Penelitian 2019

Berdasarkan data di atas menunjukkan peningkatan dari pra siklus ke siklus I sebesar $13,02 \%$, peningkatan siswa dalam keterampilan membaca pemahaman meningkat setelah dilakukannya tindakan siklus I. Sebanyak 10 orang siswa mengalami peningkatan dari hasil pra siklus, meskipun peningkatan pada siklus I belum maksimal dan belum mencapai indikator keberhasilan yang telah ditentukan, penelitian dihentikan apabila hasil perolehan siswa mencapai $80 \%$ secara klasikal.

Pencapaian pada penelitian ini dapat dilihat dari temuan pada setiap indikator keterampilan membaca pemahaman pada siklus II. Adapun hasil tes membaca pemahaman dapat dilihat pada diagram perbandingan setiap indikator yang tersaji pada gambar 4.4 sebagai berikut. 


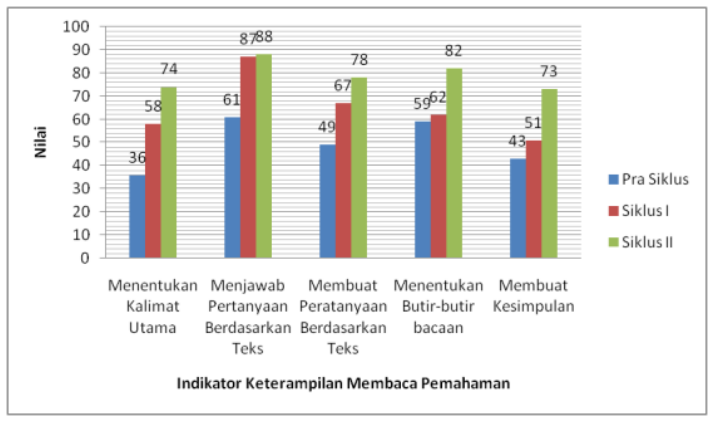

Sumber: Hasil olah data tahun 2019

\section{Gambar 4.3 Diagram Perbandingan Siklus} II Keterampilan Membaca Pemahaman

Berdasarkan data gambar 4.4 maka dapat dilihat ketercapaian dari setiap indikator keterampilan membaca pemahaman siswa pada siklus II sudah menunjukkan peningkatan dari hasil sebelumnya. Adapun deskripsi dari setiap indikator sebagai berikut.

Peningkatan keterampilan Membaca Pemahaman siswa dengan penerapan metode PQ4R pada mata pelajaran Bahasa Indonesia di kelas $\mathrm{V}$ yang telah di sesuaikan dengan indikator menurut Nutall (dalam Somadayo, 2011: 11) adalah sebagai berikut.

1) Menentukan kalimat utama

Siswa sudah mampu menentukan kalimat utama dan menjawab pertanyaan yang diberikan untuk menentukan kalimat utama. Pada indikator menentukan kalimat utama jumlah ketercapaian indikator mencapai nilai rata-rata 74 dengan kategori sangat baik. Hal ini menunjukkan bahwa siswa sudah mampu menentukan kalimat utama dan memhami isi teks bacaan. Tujuan membaca yang di kemukakan oleh Dalman (2013: 13) untuk menangkap ide pokok atau gagasan utama secara tepat, membaca untuk menemukan informasi dan memahami secara detail dan menyeluruh isi bacaan.

2) Menjawab pertanyaan berdasarkan teks

Siswa sudah mampu menjawab pertanyaan berdasarkan teks bacaan, untuk mencari isi jawaban siswa membaca teks bacaan dengan saksama. Berdasarkan hasil data ketercapaian indikator menjawab pertanyaan berdasarkan teks mencapai nilai ratarata 88 dengan kategori sangat baik.

3) Membuat pertanyaan berdasarkan tesk

Siswa dituntut untuk dapat membuat pertanyaan berdasarkan teks bacaan dengan menggunakan unsur 5W1H. Dengan membaca sekilas teks bacaan maka siswa dapat membuat pertanyaan yang berkaitan dengan teks bacaan. Kalimat tanya adalah kalimat yang bertujuan untuk memperoleh suatu informasi atau reaksi (jawaban) yang diharapkan, kalimat tanya diakhiri dengan tanda tanya.

Pada indikator membuat pertanyaan semua siswa sudah mampu membuat pertanyaan berdasarkan teks bacaan, ketercapaian indikator menjawab pertanyaan berdasarkan teks mencapai nilai rata-rata 79 dengan kategori sangat baik.

4) Menentukan butir-butir bacaan

Siswa dituntut untuk mentukan butir-butir bacaan atau informasi penting yang terdapat pada teks bacaan, berdasarkan data yang tersaji pada tabel menunjukkan bahwa siswa sudah mempu menentukan butir-butir bacaan atau informasi penting pada teks bacaan. Seperti yang dikemukakan oleh Rahim (2011: 11) bahwa tujuan 
membaca adalah untuk memperoleh informasi penting lisan maupun tulis, mengaitkan informasi baru dengan informasi yang sudah dimiliki sebelumnya dan mengaplikasikan informasi yang diperoleh dari suatu teks dalam beberapa cara lain. Adapun ketercapaian dari indikator menentukan butir-butir bacaan adalah 84 dengan kategori sangat baik, hal ini menunjukkan bahwa siswa sudah mampu menentukan butir-butir bacaan.

5) Membuat kesimpulan

Siswa sudah membuat kesimpulan atau merangkum intisari dari teks bacaan yang telah dibacanya.Berdasarkan data yang tersaji pada tabel menunjukkan bahwa siswa sudah mampu membuat kesimpulan. Seperti yang dikemukakan oleh Hodgson (dalam Tarigan, 2015: 7) membaca adalah suatu cara yang digunakan oleh pembaca untuk menemukan pesan yang ditulis oleh penulis melalui media kata-kata atau bahasa tulis. Jadi pada intinya membaca itu untuk menemukan pesan yang ditulis, salah satu cara untuk lebih memahami kita harus merangkum atau menyimpulkan apa yang penulis sampaikan. Adapun ketercapaian dari indikator membuat kesimpulan adalah 72 dengan kategori baik, hal ini menunjukkan bahwa siswa sudah mampu membuat kesimpulan.

\section{Berdasarkan peningkatan}

keterampilan membaca pemahaman dari setiap indikator telah dijelaskan disiklus II memperoleh nilai peningkatan yang berbedaan, pada siklus II siswa diberikan perlakukan dan tindakan yang sama. Hal ini karena siswa belum terbiasa untuk membaca dan membiasakannya, sehingga terbawa sampai pembelajaran. Seharunya untuk melatih keterampilan membaca pemahaman siswa, siswa harus dibiasakan untuk membaca dan memahami apa yang telah dibacanya.

$$
\text { Ketercapaian siklus II }
$$

keterampilan membaca pemahaman pada mata pelajaran bahasa Indonesia mengalami peningkatan yang signifikan dibandingkan pra siklus dan siklus I. Berikut diagram ketuntasan keterampilan membaca pemahama disajikan pada gambar 4.5 sebagai berikut.

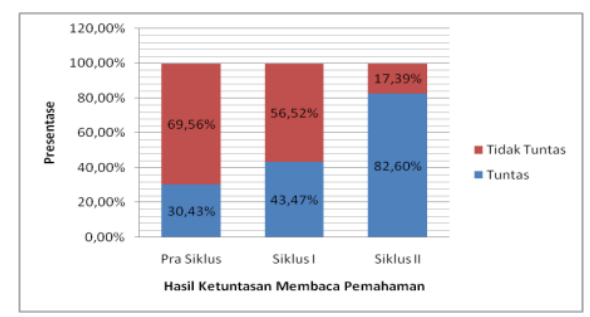

Sumber: Hasil Olah Data Penelitian 2019

\section{Gambar 4.4 Diagram KetuntasanTest Membaca Pemahaman}

Berdasarkan diagram di atas menunjukkan bahwa keterampilan membaca pemahaman pada mata pelajaran bahasa Indonesia mengalami peningkatan secara signifikan. Peningkatan tersebut sebesar 39,13\% dari siklus sebelumnya, hal ini karena pada siklus II guru memberikan tindakan secara maksimal dan siswa sudah terbiasa dengan metode yang diterapkan oleh guru, dalam satu siklus terdapat dua pertemuan, setiap pertemuan siswa di berikan tes membaca pemahaman, pada siklus II pertemuan 1 (15 orang) siswa 
$(65,21 \%)$ yang tuntas mencapai KKM, sedangkan pada pertemuan 2 (19 orang) siswa $(82,60 \%)$ mencapai KKM, sehingga data pada diagram ketuntas mengalami kenaikan secara signifikan. Terbukti dari peningkatan pra siklus, siklus I dan siklus II. Maka penerapan metode PQ4R sudah relevan dalam meningkatkan keterampilan membaca pemahaman. Siklus pada penelitian ini sudah diberhentikan karena telah mencapai indikator keberhasilan yang telah ditentukan yaitu, siklus dihentikan apabila ketuntasan siswa mencapai $80 \%$ secara klasikal.

Berdasarkan penjelasan di atas, dapat diperoleh dari hasil olah data N-Gain bahwa penerapan metode PQ4R meningkatkan keterampilan membaca pemahaman dengan kategori sedang (0.68). Hal tersebut dapat menunjukkan ketercapaian keterampilan membaca pemahaman dengan demikian metode PQ4R terbukti dapat meningkatkan keterampilan membaca pemahaman.

\section{SIMPULAN DAN SARAN}

a. Simpulan

Berdasarkan hasil temuan dan pembahasan, dapat disimpulkan bahwa keterampilan membaca pemahaman siswa kelas VA SD Negeri Cikole Kota Sukabumi meningkat dengan menggunakan metode PQ4R. Peningkatan keterampilan membaca pemahaman siswa kelas VA SD Negeri Cikole Kota Sukabumi ditunjukkan dengan adanya peningkatan kualitas proses pembelajaran dan peningkatan hasil pembelajaran. Peningkatan proses pembelajaran ditunjukkan dengan siswa lebih aktif dan antusias mengikuti proses pembelajaran menggunakan metode PQ4R.

\section{Pelaksanaan Metode PQ4R}

$$
\text { Pelaksanan keterampilan }
$$

membaca pemahaman pada mata pelajaran bahasa Indonesia pada siswa kelas V SD Negeri Cikole Sukabumi dengan menggunakan metode PQ4R. Adapun langkahlangkah pembelajaran membaca pemahaman dengan metode PQ4R pada penelitian ini adalah sebagai berikut. Tahap pertama yang dilakukan adalah tahap Preview, Question, read, reflect, recite, dan review. Berdasarkan hasil observasi aktivitas guru yang memperoleh nilai rata-rata 70 siklus 1 dengan kategori cukup. Pada tahap Read guru sudah mampu membimbing siswa dengan baik dan mengarahkan siswa untuk membaca secara keseluruhan teks bacaan. Sedangkan nilai rata-rata pada siklus 2 memperoleh nilai 88 dengan kategori sangat baik. Aktivitas siswa memperoleh nilai rata-rata 67 siklus 1 dengan kategori Cukup. Sedangkan hasil nilai ratarata pada siklus 2 adalah 86 dengan kategori sangat baik.

\section{Peningkatan Keterampilan Membaca pemahaman \\ Peningkatan hasil} pembelajaran keterampilan membaca pemahaman siswa kelas VA SD Negeri Cikole Kota Sukabumi adalah sebagai berikut presentase hasil tes membaca pemahaman siswa yang mencapai indikator yang ditentukan 
atau presentase siswa yang mencapai nilai 75 padaprasiklus mencapai $30,43 \%$ (7 orang siswa yang tuntas), pada siklus I mencapai 43,47 \% (10 orang siswa yang tuntas), dan pada siklus II mencapai 82,60 \% (19 orang siswa yang tuntas). Berdasarkan rumus N-Gain bahwa penerapan metode PQ4R meningkatkan keterampilan membaca pemahaman dengan kategori sedang (0.68). Hal tersebut dapat menunjukkan ketercapaian keterampilan membaca pemahaman dengan demikian metode PQ4R terbukti dapat meningkatkan keterampilan pemahaman.Hasil membaca menunjukkan bahwa pembelajaran keterampilan membaca pemahaman menggunakan metode PQ4R telah memenuhi indikator keberhasilan dalam penelitian ini. Sehingga penelitian ini dapat dikatakan berhasil.

\section{B. Saran}

Berdasarkan hasil penelitian (PTK) pada siswa kelas V SD Negeri Cikole Kota Sukabumi, penuliskan akan memberikan saran-saran sebagai berikut.

1. Bagi peneliti selanjutnya yang akan menggunakan metode PQ4R, berdasarkan penelitian yang telah dilakukan, metode PQ4R memerlukan waktu yang cukup dalam pelaksanaannya pada proses pembelajaran, sehingga guru harus mampu mengoptimalkan waktu yang ada dengan keenam langkah pembelajaran. Kemudian dibantu dengan penggunaan alat pendukung pembelajaran atau media pembelajaran yang relevan. Agar pembelajaran lebih efektif dan pembelajaran tidak membosankan.

2. Bagi guru, guru dapat menerapkan metode PQ4R dalam proses pembelajaran Bahasa Indonesianya khusunya keterampilan membaca pemahaman sebagai salah satu alternatif pilihan dalam meningkatkan keterampilan membaca pemahaman siswa serta untuk menciptakan proses pembelajaran yang menyenangkan, aktif, partisifatif dan relevan dengan kebutuhan siswa di Sekolah Dasar sesuai dengan tingkatan kelasnya.

\section{DAFTAR PUSTAKA}

Abidin,Y.(2012). Pembelajaran Membaca Berbasis Pendidikan Karakter, Bandung: PT Refika Aditama.

Ahmad, F.Z. (2013). "Penerapan Strategi PQ4R Untuk Meningkatkan Keterampilan Membaca Pemahaman Pada Siswa Sekolah Dasar".Jurnal Penelitian: JPGSD. 01, (02), 1-2.

Dalman. (2014). Keterampilan Membaca. Jakarta: Raja Grafindo Persada.

Daryanto, D. (2011). Media Pembelajaran Peranannya sangat Penting Dalam Mencapai Tujuan Pembelajaran. Yogyakarta: Gava Media.

Depdiknas. (2006). Kurikulum Tingkat Satuan Pendidikan Sekolah Dasar. Jakarta: Depdiknas. 
Hamzah, A. (2014). Evaluasi Pembelajaran Matematika. Jakarta: Rajawali Pers.

Ihsani, N. Kurniah, N. dan Suprapti, A. (2018). Hubungan Metode Pembiasaan Dalam Pembelajaran Dengan Dispilin Anak Usia Dini. Jurnal Ilmiah Potensia. Hlm 50-51.

Iskadarwassid \& Sunendar. (2008). Strategi Pembelajaran Bahasa. Bandung: PT Remaja Rosdakarya.

Jundaiswary. (2016). Peningkatan Kemampuan Membaca Teks dengan menggunakan Metode PQ4R (Preview Question Read Reflect Recite Review) Siswa Kelas XI SMA Negeri 14 Makassar. Tesis pada UNM Makasar: tidak diterbitkan.

Kinanthi, T.I. (2013). Keefektifan Penggunaan metode PQ4R Dalam Pembelajaran Membaca Bahasa Jerman di SMA Negeri 1 Seyegen Sleman. Skripsi pada FBS UNY Yogyakarta: tidak dipublikasikan.

Muhsin. (2010). Upaya Meningkatkan Kemampuan Membaca Pemahaman Dengan Metode Preview Question Read Reflect Recite Review (PQ4R) Pada Siswa Kelas VI MIN Susukan Kabupaten Semarang. Tesis pada Program Pascasarjana UNS Surakarta: tidak dipublikasikan.

Nadzifah, W. (2016). Upaya Meningkatkan Keterampilan Membaca Pemahaman Menggunakan Metode SQ3R Siswa Kelas IV SD N Katongan I Nglipar Gunung Kidul.
Skripsi pada PGSD FIP UNY Yogyakarta: tidak dipublikasikan.

Ngalimun. (2017). Strategi Pembelajaran dilengkapi dengan 65 Model Pembejaran. Yogyakarta: Parama Ilmu.

Rahim, Farida. (2009). Pengajaran Membaca Di Sekolah Dasar, Jakarta: Bumi Aksara.

Slamet, St.Y. (2008). Dasar-Dasar Keterampilan Berbahasa Indonesia. Surakarta: UNS Press.

Somadayo, S. (2011). Strategi dan Teknik Pembelajaran Membaca. Yogyakarta: Graha Ilmu.

Suhendar, \& Supinah. (2010). Mata Kuliah Umum Bahasa Indonesia. Bandung: CV. Pionir Jaya Bandung.

Suprijono, A. (2013). Cooperative Learning: Teori dan Aplikasi PAIKEM. Yogyakarta: Pustaka Pelajar

Susanto, Ahmad. (2013). Teori Belajar dan Pembelajaran di Sekolah Dasar. Jakarta: PRENADAMEDIA GROUP.

Syah, M. (2009). Psikologi Belajar. Jakarta: Rajawali Pers.

Syarifah, Lailatis. 2015. The Application Of PQ4R (Preview, Question, Read, Reflect, Recite, Review) Strategy To Improve Students" Reading Comprehension Of The Eighth Years Students Of Mts Nu Salatiga In The Academic Year 2015/ 2016. Tesis. 
Tidak dipublikasikan. IAIN SALATIGA.

Tarigan, H.G. (2015). Membaca sebagai Suatu Keterampilan Berbahasa.Bandung: Angkasa.

Trianto, (2015). Model-model Pembelajaran Inovatif Berorientasi Konstruktivistik. Jakarta: Prestasi Pustaka.

Wiraatmadja, R. (2012). Metode Penelitian Tindakan Kelas. Bandung: PT Remaja Rosdakarya. 
Jurnal Perseda Vol 2, No.3 Tahun 2019 | 153 